\title{
Antikvarer og oldforskning på Grundtvigs tid
}

\author{
Af Christian Adamsen
}

En præsentation af, hvad man vidste om oldtiden på Grundtvigs tid, og et forsøg på at karakterisere de måder, hvormed man greb studiet af den forhistoriske tid an: antikvarianisme, systematisering og begyndende institutioner, folkelig formidling, videnskabeliggørelse. Nogle af de vigtigste aktører og institutioner inden for oldforskningen præsenteres. Skønt den direkte kontakt mellem Grundtvig og antikvarerne var beskeden, var hans indirekte påvirkning på længere sigt betydelig.

Enhver fagdisciplin er i større eller mindre udstrækning et spejl af og står i vekselvirkning med den tid, den udøves i. Det gælder i særlig grad de fag, som beskæftiger sig med fortiden, og til dem må oldforskningen (arkæologien) regnes. Udtrykket dækker studiet af den materielle kultur i tiden før skriftkulturen, hvilket på disse breddegrader i store træk betyder tiden før kristendommen, men også i mellemalderen, det vil sige tiden indtil Reformationen. I dag kalder vi dette tidsrum for middelalderen.

I det følgende vil jeg forsøge at give en oversigt over nogle aspekter af oldforskningen på Grundtvigs tid. Uden at man kan tale om skarpe opdelinger eller faser, som afløser hinanden, er der dog alligevel nogle karakteristiske træk og fænomener eller temaer, som falder i øjnene: (a) Antikvarianisme, (b) Systematisering og begyndende institutioner, (c) Folkelig formidling, (d) Videnskabeliggørelse, herunder aflivning af myter og aktiv indsamling (udgravning). Endvidere spiller de nationale og nationalliberale strømninger i stigende grad en rolle.

\section{Antikvarianismen}

Antikvarianismen kan virke som et vel akademisk udtryk på dansk, men ordet skurrer ikke i ørerne på samme måde på svensk og engelsk, hvorfor jeg alligevel vover at bruge det. Den har her i landet sin rod i 1500-årene med Hans Svaning (den ældre) og især dennes svigersøn Anders Sørensen Vedel, fortsætter i 1600-årene med navne som Ole Worm og Bircherod'erne, men făr en opblomstring i 1700-årenes anden halvdel, oplysningstiden. Man har benyttet udtrykket "den danske topografiske tradition", som dækker over en lang række af landsdækkende videnindsamlinger (Jörgensen 1960, Poulsen 1997).

Erik Pontoppidan er en fremtrædende repræsentant for denne linje, og med hans Danske Atlas, afsluttet af svogeren Hans de Hofman, blev

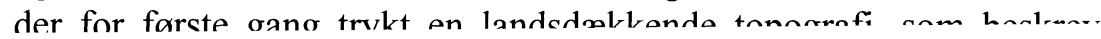


landet sogn for sogn. Men Pontoppidan har også en arkæolog i sig. Allerede 1743 offentliggør han i Videnskabernes Selskabs Skrifter en undersøgelse af en sjællandsk gravhøj, hvor han iagttager, at urner med brændte ligrester påtræffes $\mathrm{i}$ et højere niveau end grave med ubrændte lig. I al sin enkelhed er iagttagelsen banebrydende, og Pontoppidan drager i det første bind af Danske Atlas konsekvensen, idet han opdeler fortiden i to: højalderen og brændalderen (Pontoppidan 1763, 108). Oldtiden var ikke længere ét stort mørkt mulm; der er nu en ældre og en yngre del: Den empiriske iagttagelse havde meldt sig i oldforskningen.

P. F. Suhm er en anden vigtig aktør. Hans virke som historiker var ambitiøst, han påbegyndte blandt andet en Danmarkshistorie i 14 bind, og hans elev Rasmus Nyerup påtog sig at fuldføre det store værk efter forfatterens død. Det var Suhm, som i 1770 udtænkte en forklaring på menneskets indvandring til Danmark, hvilket måtte være sket før de ældste skriftlige kilder (J. Jensen 1988, 3-5). Ræsonnementet var enkelt og logisk opbygget: Det fremgår af Bibelen, at Babelstårnet blev opført præcis 101 år efter Syndfloden, som igen ud fra de detaljerede slægtsrækker indtraf 1657 år efter Skabelsen. Det tog altså menneskene 101 år at komme fra Ararat og til Babylon, og denne vandringshastighed kunne Suhm nu overføre på spredningen af folkeslagene efter den store sprogforvirring. 865 år efter Babylon 2522 år efter Skabelsen - ankom de første mennesker følgelig til Jylland. Da de som bekendt senere forlod halvøen under navnet kimbrer, rykkede andre stammer snart ind i Jylland fra øst. For Suhm var Bibelen facitlisten, suppleret af visse andre kilder. Sagn, religion og arkæologi er vævet sammen i ét charmerende kludetæppe.

Men hvordan så man egentlig på fortidsminderne, gravhøjene, $i$ det danske landskab? Oehlenschläger kunne sandelig andet end at anprise Guldhornene. I 1802 lader han i sit Sanct Hansaften-Spil (fra Digte, 1803) Harlekin komme snublende ind på scenen med ordene:

De Gravhøie skulde Fanden flytte!

De staae her og giør ikke den mindste Nytte.

Det er en Levning af Barbariet;

Jeg tror, jeg skal klage for Politiet.

Harlekin, en komisk skikkelse i Dyrehavens forlystelsesliv (overvintret fra den italienske maskekomedie), repræsenterer her 1700-årenes rationalistiske nyttesynspunkt. Hans vers er imidlertid en replik til indledningsmonologen, fremført af den gamle vandringsmand Prologus, der fra gravhøjen funderede over historien, livets store spørgsmål og endelig anråbte naturen selv: romantikkens repræsentant, som digteren selvsagt sympatiserer med. ${ }^{1}$

De store landbrugsreformer, udskiftningen, havde bevirket, at den gamle overtro ikke længere beskyttede højene ude på de fælles græsnmråder almindinoen. $\mathrm{Nn}$ skulle de væk iorden kunne fvides $\mathrm{i}$ 
vandhuller, og stenene bruges i stengærder, så bønderne kunne lette dyrkningen, øge høstudbyttet og ved hegning holde dyrene væk fra markerne.

De to første linjer indsatte Grundtvig som motto for et debatindlæg om oldtidsminder (Grundtvig 1809), som indledes med ytringen: "Da den vantrevne Forstand udjog alle Guder af deres Templer, indsatte den Nytten til deres Arving, og denne usle, krogede Uting bryster sig nu i Høisædet."

\section{$\mathfrak{D} \mathfrak{l} \mathfrak{d} \mathfrak{i} \mathfrak{a} \mathfrak{g} \mathfrak{e}$}

Rommiffionel til Dlofigers Dplevaring onfer fig unoertettet ont.

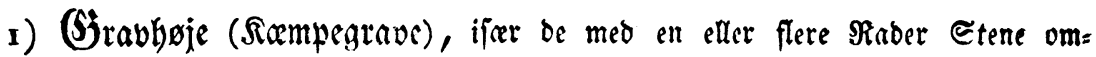
fatte, eller med ftorre Stene $i$ Sjiornerne uomarkeve, og be marketig af: lange; ligetedes Brave, fom bave elfer bave brot et, af fire ftore Stene indfattet og med en frorre tilbaflet, Bravtammet.

2) Selbenfle 2Crtere, nemlig (for bet mefte) tre opretfaaende Stene, ber ftotte unber en ftor paa bem byilende Sten; be findes (ffundom bobbelte) enten paa flet MatE ellit paa en \$coj.

3) Singftebcr, nemlig aflange Splabjer inbfattede med temmetig fore Stene.

4) Store oprejife Sitene (Bautaftene), famt i Slipper inohugne Billeber eller SFrift.

5) Runeftene, buab enten be enonu ftaae bele og bolome paa Mark, 5̧øi, Rirkigaard, eller fibde inomurede $i$ Sirker eller Sirkegaardsmnre, Sjicrber og bestige, eller ligge i Rirkegulve, Broer, Babfteder; bcle sller Styt: ter af bem.

De flefte Runer ljave benne Ekikelf:

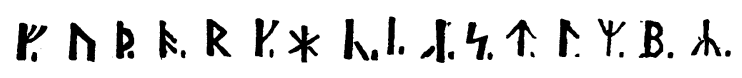

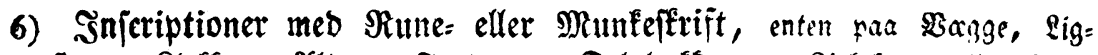
ftene, Rlokfer, 2ultere, Fonter og Dobebafkener, Sirfétar, cller brot: fombelit.

Runkeftrift beftaaer af latine Bogftaver, fom paa mange Manter ere giorte fantede og fnoebe: f. Ex.:

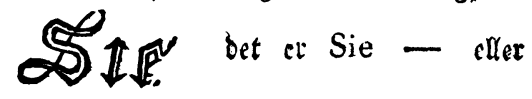
59. Det er Ar. 


\section{Systematisering}

I 1807 blev der, midt i Englandskrigenes værste år, nedsat en kongelig kommission. Krigsårene havde frembragt nationale strømninger, og både landbrugsreformerne og vejforordningen af 1793 havde kostet dyrt set fra fortidsmindernes side. Kommissionen, hvis opgave var at indsamle oplysninger, bevare fortidsminder i landskabet og at sprede viden, udviklede sig efterhånden til det museum, som siden 1892 har båret navnet Nationalmuseet.

Nedsættelsen af kommissionen kom efter en målrettet agitation i de trykte medier fra litteraturprofessoren Rasmus Nyerup og teologen (fra 1808 biskop) Frederik Münter, som begge ved selvsyn kunne rapportere om nyligt ødelagte fortidsminder fra egne, hvor de havde færdedes som unge. Mens Nyerup var fæstehusmandssøn med en $\mathrm{H}$. C. Andersen-agtig kometkarriere, var Münter som søn af den tyske præst i St. Petri Kirke nærmest født ind i de orientalske og antikvariske fag. A. W. Hauch, hofmarskal med et organisationstalent og en enorm arbejdskraft sikrede den direkte kanal til kongen, P. J. Monrad den direkte kontakt til centraladministrationen. Professor Børge Thorlacius og kaptajn W. H. F. Abrahamson rundede flokken af (Adamsen \& Jensen 2003, 61-88).

Blandt de første initiativer var udsendelsen af en spørgeliste i 12 punkter med en opregning af forskellige emner, man ønskede sig oplyst om - dels det vi i dag vil kalde forhistoriske anlæg og genstande, dels kirkeinventar fra før Reformationen, eller "den katholske Cultus", som det hedder. Mange svar og genstande blev resultatet. Mindre heldig var den udtrykkelige tilføjelse til spørgelistens punkt 8: "Ogsaa om i Pladen, der undertiden dækker Alterbordet, endnu findes de firkantede Fordybninger lukkede med en liden Sten, i hvilke fordum laae og maaskee endnu findes Reliqvier eller Documenter." Det skulle man nu aldrig have skrevet. Energiske præster gik i gang med hammer og brækjern, men rapporterer ofte skuffet tilbage, at de kun fandt en lille stump træ, en knogle, lidt lærred og noget pergament med ulæselige bogstaver på - det kan have været en stump af Kristi kors, en splint af den hellige Jakob, byzantinsk silke og bønner. Opdagelsesiveren førte til uforsætlig destruktion af fornemme relikvier, som havde ligget uforstyrret i et halvt årtusinde eller længere. Indberetningerne udgør et spændende, skønt meget uensartet kildestof, som ikke blot viser, hvad man mente at vide om oldtiden i hver eneste præsts studerekammer - et landsdækkende stykke lærdomshistorie - men også afspejler den samlede fond af viden, som kommissionen havde adgang til i København (Adamsen \& Jensen 1995-2003).

Man samlede og samlede, beskrev og beskrev. Samtidig med arbejdede Grundtvig på sit kammer på Valkendorfs Kollegium på sin 
Nordens Mytologi (1808), mens Blicher lagde sidste hånd på oversættelsen af Ossians digte. Frederik Münter var kollegiets efor.

Rasmus Nyerup havde den tilsvarende post på Regensen. Der er næppe tvivl om, at begge eforer knyttede mange venskaber med studenterne, de kommende præster, og disse personlige forbindelser hjalp uden tvivl på længden og kvaliteten af en del af præsternes besvarelser af spørgelisten.

Efter samlernes årti 1807-16 fulgte et halvt århundrede, som blev tegnet af en dygtig syntesemager og organisator, genial forsker og blændende formidler: Christian Jürgensen Thomsen afløste Nyerup på posten som sekretær i Oldsagskommissionen ved årsskiftet 1816/17, året før Grundtvig udsendte de to bind af sine oversættelser af Saxo og Snorre. Enhver, der har læst Jules Vernes Rejsen til Jordens Indre fra 1864 (og hvem har ikke det?), har næsten truffet denne hjælpsomme, åbne og vidende mand, som hjalp de to tyske ekspeditionsdeltagere til rette under deres korte ophold i København, før de drog videre til Island. Thomsen var en selvlært naturbegavelse, som kunne begå sig lige let blandt bønder som mellem fyrster.

Fra rejsebeskrivelser ved vi, at treperiodesystemet, det vil sige den epokegørende opdeling af oldtiden i stenalder, bronzealder og jernalder, lå bag grupperingen af de udstillede oldsager i skabene på Trinitatis Kirkeloft, men nogle nyligt genfundne lister peger længere tilbage, mod 1812 (Madsen \& Jakobsen 1999). Historikeren Vedel Simonsen nævner i øvrigt treperiodesystemet 1813, den skånske museumsmand Nils Henrik Sjöborg gør det i 1815, men allerede i Oldsagkommissionens spørgeliste fra august 1807 antydes det i virkeligheden under punkt 10 på denne måde: "Sten, Kobber- og Jernvaaben." De homeriske digte, som menes nedskrevet i græsk jernalder, omtaler sagnpersonernes bronzeredskaber, så ethvert nogenlunde dannet menneske havde mulighed for at komme på sporet af denne udvikling eller sekvens. Der er skrevet meget om, hvem der kom først med denne indsigt, men spørgsmålet er vel, om dette æresspørgsmål er så vigtigt igen.

Man kan måske drage en parallel til H. C. Ørsteds opdagelse af elektromagnetismen, hvor nogle franskmænd arbejdede med de samme problemer og måske, måske ikke indså sammenhængen mellem magnetisme og elektricitet før Ørsted. Efter min mening er det publikationen, dokumentationen og erkendelsen af en opdagelses konsekvenser, der er det centrale. Og her er man ikke i tvivl om hvem æren bør tilfalde, for Thomsens værk, i dag kendt som Ledetraad for nordisk Oldkyndighed (1836), men som rettelig bærer titlen "Kortfattet Udsigt over Mindesmærker og Oldsager fra Nordens Fortid" (idet det efterfulgte N. M. Petersens i dag glemte artikel "Den oldnordiske Literaturs Omfang og Vigtighed" i en fælles udgivelse fra Oldskriftselskabet) er et prægtigt lille arbejde på blot 63 sider med mangfoldige 
iagttagelser af mange forskellige oldtidsfænomener og -sammenhænge og en detaljeret argumentation. Thomsens tese blev præsenteret sent, og hans navn er nævnt $\mathrm{i}$ forordet, men ikke på titelbladet. Man kan derfor dårligt påstå, at han deltog særligt energisk i noget akademisk kapløb. Treperiodesystemet repræsenterer et evolutionært syn på den materielle kulturhistorie, længe før Darwin revolutionerede biologien.

\section{Institutioner}

Med Oldsagskommissionen dannedes der hurtigt en samling, hvortil der var offentlig adgang. Blandt forbillederne var antagelig den naturhistoriske samling, og også i dén kommission var Hauch formand (ligesom han var det for Kunstkammeret og Den kgl. Mønt- og Medaillesamling). I 1812 anlagde kommissionen en publikation, Antiqvariske Annaler, som fra 1825 blev videreført af Det kongelige nordiske Oldskriftselskab som årbog, og som sådan lever serien videre den dag i dag, nu under titlen Aarbøger for nordisk Oldkyndighed og Historie. Kommissionen tog også initiativer til fredning, det vil sige en vedvarende beskyttelse af monumenter i landskabet. Men desværre skete der ikke tinglysning, så initiativerne fik ikke varig retsvirkning. Ikke desto mindre eksisterer nogle af disse såkaldte kancellifredede anlæg den dag i dag. Grundtvigs holdning var, at høje med tilknyttede sagn, stensætning hvor syslets mænd havde holdt ting eller blot, og gravhøje placeret i en stor cirkel burde bevares, og "intet Sogn, som eier Høie, bør aldeles blottes." Om gravhøje på præstens egen jord skriver han: "En Usling maa han være, hvis han finder det Bud haardt, at lade den stande urørt" (Grundtvig 1809, sp. 1664). Var hans synspunkt slået igennem, så det danske landskab ganske anderledes ud i dag. Dengang var det dog urealistisk, idet det ignorerede ejendomsretten og ikke forholdt sig til erstatningsspørgsmålet.

At udforske, at bevare, at udstille, at publicere: Alt dette havde Frederik Münter set på sit flerårige ophold i Sicilien i 1786-87. Jeg er derfor overbevist om, at hovedidéen til Oldsagskommissionen kommer fra Italien.

Grundtvig brød sig i øvrigt ikke om Oldsagskommissionen. Han mente, at alle udyrkede gravhøje skulle ejes af Kongen og dermed af nationen. Oldsager havde han hverken sans eller forståelse for. Den 26. august 1808 drog Christian Molbech ud på en herlig ekspedition med "sin nordiske Ven", N. F. S. Grundtvig, og kort efter trykte Molbech en levende skildring i Nyeste Skilderie af Kjøbenhavn (senere genoptrykt i Ungdomsvandringer $i$ mit Fødeland (1811). Molbech, som ellers var en nøgtern mand, beskriver, hvordan

ei uden en vis Gysen gik vi frem i det høitidsfulde Mørke; i Skovens Skumring maatte vi med spændt Opmærksomhed give Agt paa den Fodsti til Gunderslevholm, hvis svage, næsten udslettede Spor skulde 
være os Lys paa vor Vei (Adamsen \& Jensen 2003, 30-31).

Det er det senere møde med en prægtig langdysse (bevaret den dag $\mathrm{i}$ dag), som făr Grundtvig til at skrive det kendte digt "Gunderslev Skov" med de afsluttende verslinjer:

Jeg iler, jeg iler med vingede Fjed,

For Asernes Alter at kaste mig ned,

Og prise de hensovne Guder.

Der har været peget på det påfaldende i, at digtet fik navn efter Skoven og ikke efter Alteret. Skønt det er fascineret af oldtidsreligionen, er det netop ikke noget programskrift for at genoplive asatroen (LundgreenNielsen 1980, 245-249).

\section{Folkelig formidling}

Oldsagskommissionens spørgeliste skulle sikre viden til kommissionsmedlemmerne i København, men er jo samtidig en kommunikation den anden vej. Resultater blev, at hver eneste præst og en del andre embedsmænd i 1808-09 modtog denne korte, men overskuelige information om levn fra fortiden. Viden og et vist fælles sprog er den første naturlige forudsætning for at forstå og rapportere om nye iagttagelser, og i årene efter indløb der mange uopfordrede, opfølgende breve til kommissionen om nye fund.

Ledetraad blev fordelt til alle landets præster og lærere. På dansk i Kongeriget, på tysk i Hertugdømmerne. Det fik enorm betydning, fordi hver eneste modtager nu havde en slags lille leksikon over oldsager, oven i købet illustreret. I hvert sogn landet over var der nu mindst to mænd, som havde mulighed for at vurdere og beskrive nye fund: præsten og læreren. En betydelig tilvækst til Nationalmuseets samlinger blev resultatet. Ledetraad er et imponerende stykke folkeoplysning, skrevet i et jævnt, klart og ligefremt sprog.

I $1843 \mathrm{skrev}$ Jens Jacob Asmussen Worsaae den lille, men banebrydende bog Danmarks Oldtid, oplyst ved Oldsager og Gravhøje. Her grundlagde han en tradition, som er enestående i Europa, og som endnu er levende - nemlig at skrive et bredt anlagt oversigtsværk om dansk arkæologi fagkyndigt og dog let forståeligt. Senere er flere fulgt direkte i hans fodspor, hver gang med stigende sidetal: Sophus Müllers Vor Oldtid (1897), Johannes Brøndsteds Danmarks Oldtid (I-III, 193740) og Jørgen Jensens Danmarks Oldtid (I-IV, 2001-04). P. V. Glob greb derimod aldrig muligheden, måske fordi hans gamle lærer Brøndsted blokerede markedet med sin helt omarbejdede 2. udgave (1957-60) og med det første bind "De ældste tider" i Politikens Danmarkshistorie (redigeret af John Danstrup og Hal Koch, 1963). 


\section{Videnskabeliggørelse}

Videnskabeliggørelse har flere facetter, en af dem var aflivning af gamle myter. Den helt unge J. J. A. Worsaae, amtsforvaltersøn fra Vejle, tog ganske hårdt fat. Allerede som 20-årig gik han 1841-42 i felttog mod N. M. Petersen, som havde identificeret et moselig fundet 1835 i Haraldskjær Mose som Dronning Gunhild, den norske Erik Blodøkses dronning. Argumenterne var oplysninger i sagaer og et lokalt stednavn. Worsaae analyserede argumenterne ét for ét og gendrev dem alle. Han afviste, at jordfundne oldtidslevn kunne kobles sammen med usikre, langt senere skriftlige kilder (Hvass 1998). Den arkæologiske kildekritik havde holdt sit indtog.

Blot to år senere aflivede Worsaae en anden myte, som gik helt tilbage til Saxo. Absalons flittige krønikeskriver berettede, at der på klippen Runamo i Blekinge fandtes en runeindskrift, som Harald Hildetand skulle have ristet. I 1838 præsterede Finn Magnuson at læse indskriften, som efter hans mening var et oldnordisk kvad med stavrim. Worsaae rejste til Blekinge med en tegner, hver sprække blev minutiøst undersøgt, der blev foretaget afstøbninger og tegninger. Dommen var klar, indskriften var et naturfænomen og altså purt tankespind (Kjems i tryk). Den videnskabelige dokumentation af feltiagttagelser var nu taget $\mathrm{i}$ brug. Jørgen Jensen karakteriserer den unge himmelstormers indsats med disse ord: "med militærisk præcision og kølig beregning havde Worsaae placeret sin bombe midt $\mathrm{i}$ oldgranskernes kreds og fået frigjort arkæologien af den litterære gransknings omklamring" (Jensen 1992, 298).

Et andet aspekt af arkæologiens videnskabeliggørelse er den aktive indsamling af nyt kildemateriale ved målrettede udgravninger. Også her blev Worsaae banebrydende. Allerede fra barnsben havde han grundlagt sine erfaringer, som snart udvikledes.

Et tredje aspekt er publiceringen, hvor Det kongelige nordiske Oldskriftselskabs årbog lagde spalteplads til en strøm af afhandlinger, beskrivelser af nye fund, osv. Via et forbløffende internationalt byttenetværk blev resultaterne spredt over hele verden og sikrede dermed dansk arkæologi et betydeligt ry (Jensen \& Jensen 1988). I tilgift modtog man en enorm mængde af udenlandske publikationer, der gjorde og fortsat gør Nationalmuseets biblioteker særdeles velforsynede for få midler.

Udgravningerne og publikationerne betød en voldsom videnseksplosion: Fonden af oplysninger om gravskikke, redskabs- og smykkeformer øgedes hele tiden. Man begyndte efterhånden at opdele de tre Thomsenske perioder: Stenalderen blev omkring 1850 tvedelt i én tid med uslebne og én med slebne redskaber, svarende til fangst- og bondeerhverv. Worsaae opdager, at østersskaldyngerne indeholder mennesketildannede redskaber og altså er affaldsdynger og ikke natur- 
lige banker - køkkenmøddinger. Bronzealderen blev omkring 1860 opdelt $i$ en ældre del med jordfæstegrave og en yngre med brandgrave af forskellig art, osv. Ornamentik på smykker blev analyseret, og importstykker fra fjerne egne gav vigtige dateringsoplysninger.

\section{Afslutning}

Forholdet mellem Grundtvig og antikvarerne var næppe hverken tæt eller hjerteligt. Der var efterhånden kommet en dyb afgrund mellem de måder, man anskuede fortiden på. Langt senere skulle det vise sig, at folkehøjskolernes (antityske) vægt på dansk historie og fortid fik stor afsmittende virkning på seminarierne og lærerne - og var én afgørende faktor i den proces, som med tiden gjorde arkæologien til en førende folkehobby i 1900-årenes Danmark. To markante regenters, Frederik VII's og Margrethe II's, lidenskabelige interesse for faget har givet haft $\sin$ betydning. Johannes V. Jensens agitation for Naturfredningsloven (1937), som muliggjorde fredning af fortidsminder uden erstatning, og for den store folkeindsamling til gavn for det stærkt udvidede Nationalmuseum er endnu en faktor. ${ }^{2}$

Et barokt eksempel på, hvordan museumsfolkene så på den aldrende Grundtvig, fremgår malende af et brev, som museumsmanden Adolph Strunk 14. september 1872 skrev til sin foresatte, J. J. A. Worsaae, som lige var kommet hjem fra en rejse:

Den Vartou Kjællingepræst er da endelig reist af og begravet under frygtelig Staahei. Han var dog igrunden en hæslig gammel Karl, en rigtig Ufredsmand, saavel i Kirken som i Staten. Han blev da høilagt paa Kjøgegaard, der i Fremtiden rimeligviis bliver et Valfartssted for Vorherres egne Børn. Aldrig har jeg seet en saa uordentlig Procession, som da de grundtvigianske Præster droge forbi Palaiet; de hellige Mænd gik imellem hverandre, ligerviis som en Flok Stude. Den Guds Mand Birkedal tog en anden Præst om Halsen, idet han gik forbi, og en anden Præst klappede en "Kvinde" paa Skulderen. Det var formodentlig hans Kone eller Datter, men det stod intetsteds skrevet. Gud maa vide hvem der nu skal være Pave og hvem der bliver Præst $\mathrm{i}$ Vartou (Lindhardt 1978).

Organisationen Danske Museer (ODM) indviede for resten sit kontor i Vartov 17. maj 2006.

\section{Litteraturliste}

\section{Værker af Grundtvig}

Grundtvig, N. F. S. (1808), "Nordens Mytologi" i Holger Begtrup (udg.) (1904-09), Nik. Fred. Severin Grundtvigs Udvalgte Skrifter, bind 1, København, 241-372.

— (1809), "Et Par Ord om vore Oldtids Minder", Nyeste Skilderie af 
Kjøbenhavn Nr. 104, sp. 1662-1665, 7. Okt. 1809.

\section{Værker af andre forfattere}

Adamsen, Christian \& Jensen, Vivi (red.) (1995-2003), Danske proesters indberetninger til Oldsagskommissionen af 1807. - Vestog Sydjylland (1995), Nord- og Østjylland (1996), Bornholm, Lolland-Falster og Fyn (1997), Sjæelland, Samsø og Møn (1998), Tilloeg og registre (2003), Højbjerg.

Baudou, Evert (2004), Den nordiska arkeologin - historia och tolkningar, Stockholm.

Hermansen, Victor (1931), "Oprettelsen af 'Den Kongelige Commission til Oldsagers Opbevaring i 1807'", Aarbøger for nordisk Oldkyndighed og Historie, 265-320.

— (1953), "Baggrunden for Oldsagskommissionen", Aarbøger for nordisk Oldkyndighed og Historie, 157-202.

Hvass, Lone (1998), Dronning Gunhild - et moselig fra jernalderen, København.

Jensen, Inger \& Jensen, Jørgen Steen (1988), "Det Kongelige Nordiske Oldskriftselskabs breve 1825-1864. Dansk kulturformidling på verdensplan", Aarbøger for nordisk Oldkyndighed og Historie 1987, 211-273.

Jensen, Jørgen (1988), "Christian Jürgensen Thomsen. An Appreciation in the Bicentennial of his Birth", Acta Archaeologica vol. 58, 1987, 1-15. København.

— (1992), Thomsens Museum. Historien om Nationalmuseet, København.

Jörgensen, Harald (1960), "Resen - Pontoppidan - Trap. Grundlæggerne af studiet af dansk topografi", Nordisk tidskrift 'för vetenskap, konst och industri, ny serie, 334-348.

Kjems, Rud (i tryk), Runamo - skrıften der kom og gik, Højbjerg.

Lindhardt, P. G. (medd.) (1978), “ - den Vartou Kjællingepræst” i Arbog for dansk skolehistorie (= Festskrift til Roar Skovmand 15. juli 1978), 54-56. (Brev fra A. Strunk til J. J. A. Worsaae bl.a. om Grundtvigs begravelse.)

Lundgreen-Nielsen, Flemming (1980), Det handlende ord. N. F. S. Grundtvigs digtning, litteraturkritik og poetik 1798-1819 i Skrifter udgivet af Grundtvig-Selskabet XVI, København.

Madsen, Helge Brinch \& Jakobsen, Tove B. (1999), "1812inventarierne. En museumshistorisk undersøgelse", Aarbøger for nordisk Oldkyndighed og Historie 1997, 231-288.

Pontoppidan, Erik (1763), Den Danske Atlas Tom. I. København (genoptrykt 1969).

Poulsen, Bjørn; Fritzbøger, Bo og Jensen, Jens William (red.) (1997), "Den topografiske tradition", Bol og By. Landbohistorisk Tidsskrift, 1997:1. 
Rasmussen, Holger (1979), Dansk museumshistorie. De kulturhistoriske museer. Scrudgave af Arv og eje, Hjørring.

Thomsen, Christian Jürgensen (1836), "Kortfattet Udsigt over Mindesmærker og Oldsager fra Nordens Fortid" i Ledetraad til Nordisk Oldkyndighed, 27-90. København.

\section{Noter}

Denne artikel er baseret på et foredrag holdt ved Center for Grundtvigstudier, Aarhus Universitet i marts 2006 om temaet Grundtvig og den tidlige tradition.

1 Jeg takker Flemming Lundgreen-Nielsen for supplerende oplysninger om dette emne samt om Martin A. Hansen (se nedenfor). For andre nyttige kommentarer og afgørende henvisninger takker jeg professor S. A. J. Bradley og professor Christian Thodberg.

2 Martin A. Hansen har i sit monumentale Orm og Tyr (1952), 32-34, med udgangspunkt i Gunderslev-dyssen og Grundtvigs fortolkning af denne argumenteret for at genoptage forbindelsen mellem skriftlige kilder og arkæologiske fund og mindesmærker. Emnet er behandlet af Birgitte Krejsager: Fortcellerens rum. Et studie $i$ Martin A. Hansens Orm og Tyr (1996). 